410 筋電信号による腕の動作識別と関節角度推定

\title{
Motion Discrimination and Joint Angle Estimation of an Arm using EMG Signals
}

\author{
$\bigcirc$ 北村 徹 （同志社大院） 正 辻内 伸好（同志社大） \\ 正 小泉 孝之（同志社大）
}

\begin{abstract}
Toru KITAMURA, Graduate School, Doshisha University, Tataramiyakodani, Kyotanabe, Kyoto Nobutaka TSUJIUCHI, Doshisha University, Tataramiyakodani, Kyotanabe, Kyoto

Takayuki KOIZUMI, Doshisha University
\end{abstract}

\begin{abstract}
The position tracking and control method using the bioelectrical signals attracts attentions as expectable technology. The purpose of this research is to construct a practical master slave system, which uses electricmyogram (EMG) signals. Signal processings of EMG signals are performed using a linear multiple regression model, which can learn parameters in a short time. Using this model, joint angles are predicted, and the motion pattern discrimination is conducted. Several experiments were conducted to verify the validity of this technique. First, the motion pattern discrimination from EMG signals was conducted. Discriminated motions were flexion, and abduction at a shoulder joint, and flexion, extension, pronation, and supination at an elbow joint. Second, the experiment using a robot arm was conducted. In this experiment, an arm joint angle was predicted from EMG signals. From these experiments, the usefulness of processing EMG signals with a linear multiple regression model was proved.
\end{abstract}

Keywords: EMG, Linear Multiple Regression Model, Pattern Recognition, Human Interface

\section{A1. 緒言}

近年，ロボットのマスタ・スレーブ制御のためのインタ フェースとして生体信号の一つである表面筋電信号が注目 されている．そのため筋電信号から人腕の運動を推定する 研究が数多く行われているが，その多くは関節トルクの推 定を行っている。しかし一般に人腕とロボットのダイナミ クスは異なるためトルクの推定だけではロボットを制御で きない。また，これらの研究ではニューラルネットワーク を用いて推定を行っているので多大な時間を必要とする. そこで本研究では, 短時間で最適解が求まる重回帰モデル を用いて筋電信号から时の関節角度の推定を行う手法を提 案する。 また誤動作を防止するため筋電信号から動作識別 を行う手法を提案する．さらにマニピュレータを用いた実 験により提案手法の有効性を検証する.

\section{A2. 理論}

関節角度は過去の関節角度と $d$ チャンネルで計測された 筋電信号の整流・平滑化した信号の線形和として表現でき ると仮定し，以下のような重回帰モデルを考える.

$$
\theta_{r e f}(T)=\sum_{l=1}^{d} A_{i} e m g_{l}+B \theta_{r e f}(T-1)+C
$$

ここで, $\theta_{r e f}(T), \theta_{r e f}(T-1)$ はそれぞれ現在と 1 サンプル前 の関節角度, $e m g_{i}$ はチャンネル数 $l(l=1,2, \cdots, d)$ で計測し た筋電信号を整流・平滑化した信号である。また， $A, B$, $C$ は偏回帰係数であり, 最小二乗法によって推定する.

また, 動作 $i$ に対応する動作信号 $y_{i}$ と筋電信号には線形 関係があると仮定し，以下のような重回帰モデルを考える。

$$
y_{i}=a_{i 0}+a_{i 1} e m g_{1}+a_{i 2} e m g_{2}+\cdots+a_{i d} e m g_{d}
$$

ここで $a$ は偏回帰係数であり最小二乗法によって推定する ある動作が行われた時，動作信号が最大となる動作を識別 結果とする。

\section{A3. 実験}

動作識別実験と関節角度推定実験を行い, 提案手法の有 効性を検証する.

動作識別実験では, 肩関節の屈曲, 外転動作の識別, 及 び肘関節の屈曲, 伸展, 回内, 回外動作の識別を行う。そ の結果，全被験者において90[\%]以上の識別率であった。

関節角度推定実験では，推定した関節角度と目標角度を ディスプレイ上に表示し，推定角度が目標值に追従するよ うに被験者が運動を行い, 関節角度の推定精度を検証する. 静的な目標值に対する精度は両関節とも平均追従誤差は $5[\mathrm{deg}]$ 以下となり，追従精度が高いことがわかる，動的な 目標值に対しては 25[deg]以下であったが, 推定軌道は目標 軌道に対して波形の傾向が良く一致していた。その誤差の 原因はディスプレイの表示に時間遅れと考えられる.

最後に動作識別と関節角度推定を組み合わせることに より，屈曲伸展動作以外の動作の推定関節角度への影響を 除去する. その結果より提案手法の有効性を実証した。

\section{A4. 結言}

本研究では，筋電信号を用いたロボットマニピュレーシ ヨンシステムの構築を目的とし，筋電信号から動作識別と 関節角度推定を行う手法を提案した。提案手法の有効性を 検証するため, 肩関節及び肘関節の動作識別実験を行った。 さらに関節関節角度を推定し, マニピュレータの制御実験 を行った. その結果, 以下の結論を得た。

1. 提案手法によって人腕における動作識別が可能である.

2. 提案手法によって関節角度を高精度に推定することが できた。

3. 構築した筋電制御型マニピュレーションシステムは個 人差に適応でき, 直感的な操作が可能である. 


\section{1. 緒言}

現在，ロボットのマスタ・スレーブ制御のためのインタ フェースとして，ジョイスティックやマスタアーム，ゴニ オメータなどが用いられている. しかし，ジョイスティッ クによる操作は直感的でないためオペレータに訓練が必要 である。またマスタアームやゴニオメータは手や腕などに 装着する必要があり，オペレータの運動を拘束するといっ た問題点がある. 近年, これらの問題を解決するインタフ エースとして生体信号の一つである表面筋電信号が注目さ れている ${ }^{1)}$ ，表面筋電信号とは筋肉が収縮する際に生じる 活動電位を皮膚表面で計測した電気信号であり，運動の意 志や力の大きさなどの情報を含んでいる。このため筋電信 号から人腕の運動を推定する研究が数多く行われているが, その多くは筋電信号から関節トルクの推定を行うものであ る ${ }^{2-6)}$. 人腕とロボットのダイナミクスが同じであれば推 定したトルクを使用することでロボットを制御できるが， 一般に人腕とロボットのダイナミクスは異なる，そのため 関節トルクではなく関節角度を推定する研究も行われてい $ろ^{7,8)}$.これらの研究ではニューラルネットワークを用いて 筋電信号から関節角度を推定しているが，ニューラルネッ トワークの学習には多大な時間を必要とし, 学習が収束し ない場合や局所解となってしまう場合もある。

また，筋電信号から関節角度を推定する場合，一つの筋 肉が複数の動作に関与するために同じ電極から計測される 筋電信号がある単一の動作に対応しているとは限らない。 そのため筋電信号から単純に関節角度を推定するだけでは 誤動作が生じる可能性がある。これを防止するために筋電 信号から動作識別を行う必要があると考えられる．筋電信 号からの動作識別は筋電義手の多機能化に関する研究にお いて数多く行われている ${ }^{9-12)}$. 動作識別にはニューラルネ ットワークが多く用いられているが，前述のような問題点 があるため，実用的であるとは言いがたい，一方，独立成 分分析によって回帰係数を決定した重回帰モデルを用いて 動作識別を行う研究 ${ }^{13)}$ があるが, 多くの筋電信号を計測す る必要があった。

本研究では短時間で最適解が求まる重回帰モデルを用い て, 表面筋電信号から関節角度の推定と動作識別を行う手 法を提案する．関節角度の推定にはモデルの入力として筋 電信号だけではなくマニピュレータの現在の角度も利用す ることで推定角度の精度向上を図る．また，動作識別のた めに用いる重回帰モデルの回帰係数は独立成分分析によっ て推定するのではなく,動作に対応した教師信号を与えて， 最小二乗法により推定する.この動作識別手法の有効性を 検証するため動作識別シミュレーションを行う。さらに, 動作識別と関節角度の推定手法を組み合わせて, 所望の動 作を行った時のみマニピュレータを制御し，その他の動作 を行った際には現状の姿勢を維持する切り換え制御法を提 案する. そして，提案手法を適用した筋電制御型マニピュ レーションシステムを構築し，実験によりその有効性の検 証を行う。

\section{2. 信号処理システム}

筋電信号からマニピュレータの制御入力を生成するた めの信号処理方法について述べる。 まず前処理として, 計 測された筋電信号を A/D 変換し，全波整流した後，ローパ スフィルタによって平滑化を行う。この処理を施した筋電 信号から関節角度の推定を行う。しかし一つの筋肉が複数 の運動に関与するため, 同じ電極から計測される筋電信号 がある単一の動作に対応しているとは限らない，そのため 単純に関節角度の推定を行うだけでは他動作の影響を受け, 誤動作が生じる可能性がある。これを防止するためには筋 電信号から関節角度の推定だけではなく，動作識別も行う 必要がある。そこで関節角度の推定と動作識別を組み合わ
せて，図1に示すような信号処理システムを構築する。

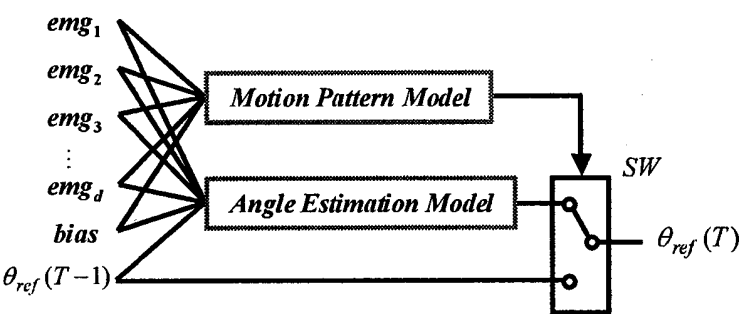

Fig.1 Signal Processing

このシステムでは筋電信号から動作識別を行うことで，対 応した動作を行った時のみ推定した関節角度をマニピュレ 一タへ入力し，対応していない動作を行った際には現状の 関節角度を保つような切り替え制御を行う。本研究では, 矢状平面上における屈曲伸展動作を行ったときのみ推定角 度をマニピュレータの指令角度とし, その他の動作を行っ た際は現在の関節角度を維持する. 以下, 3 章で関節角度 の推定方法, 4 章で動作識別の方法について説明する.

\section{3. 関節角度推定}

\section{1 関節角度推定モデル}

関節角度は過去の関節角度と整流，平滑化された筋電信 号の線形和として表現できると仮定し，以下のような重回 帰モデルを考える。

$$
\theta_{r e f}(T)=\sum_{l=1}^{d} A_{i} e m g_{l}+B \theta_{r e f}(T-1)+C
$$

ここで, $\theta_{r e f}(T), \theta_{\text {ref }}(T-1)$ はそれぞれ現在と 1 サンプル前 の関節角度, $e m g_{i}$ はチャンネル数 $l(l=1,2, \cdots, d)$ で計測し た筋電信号を整流・平滑化した信号である。また， $A, B$, $C$ は偏回帰係数であり, 最小二乗法によって推定する.

\section{2 学習方法}

モデルの回帰係数を学習する際に, 教師信号として実際 の関節角度を与える必要がある. ポテンショメータなどの 位置計測装置を用いて関節角度を計測する方法も考えられ るが, 本研究では実際の関節角度を計測せずに教師信号を 与える方法を用いる.

まず，次式に示すチャープ信号を指令值としてマニピュ レータを制御する。

$$
\theta_{t}(t)=-A \cos \left[2 \pi\left\{\left(f_{2}-f_{1}\right) \frac{t}{\Delta t}+f_{1}\right\} t\right]+A
$$

この指令値は振幅が $A$ で，周波数が $f_{1}$ から $f_{2}$ まで時間 $\Delta t$ で変 化する. 被験者はマニピュレータの運動を見ながら同様の 運動を行う。この時のマニピュレータへの指令值を教師信 号とし，筋電信号とマニピュレータの関節に取り付けられ たエンコーダの值を説明変数の学習用サンプルデータとし て使用する．学習の様子を示した図を図2に示す.

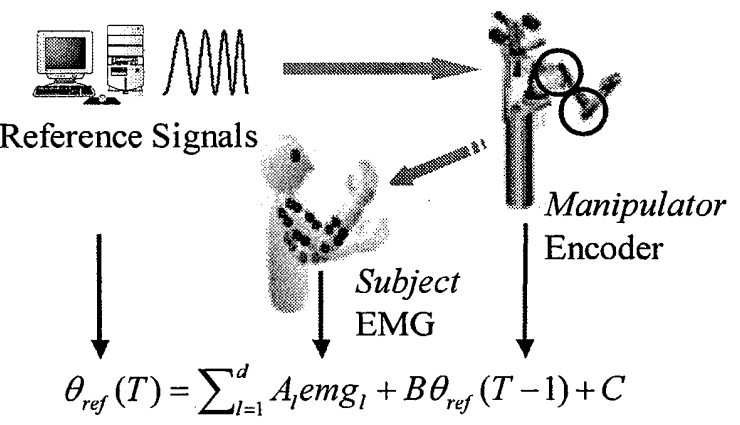

Fig.2 Data Collection for Training the Model 


\section{4. 動作識別}

動作識別を行うために重回帰モデルを用いて, 筋電信号 から対応した動作を行った時のみ正になる信号（以下，動 作信号と呼ぶ）を生成する. 動作ごとにモデルを作成し， 出力值である動作信号によって動作の識別を行う。ある動 作が行われた時, 動作信号が最大となる動作を識別結果と する. 本研究では図 3 に示す肩関節における外転動作, 屈 曲動作及び肘関節における屈曲動作, 伸展動作, 回内動作, 回外動作に対応する動作信号を生成する，モデルの偏回帰 係数を学習するためには, 教師信号が必要である. 本研究 では筋電信号から動作に対応した教師信号をリアルタイム で生成し偏回帰係数を推定する手法を提案する.

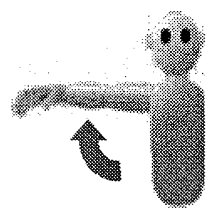

Abduction

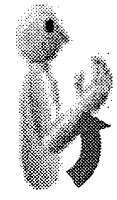

Flexion

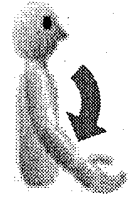

Extension

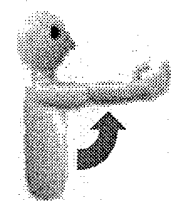

Flexion
Fig.3 Motions of Shoulder and Elbow

\section{1 動作推定モデル}

動作 $i$ に対応する動作信号 $y_{i}$ と $d$ チャンネルで計測され た表面筋電信号を整流・平滑化した信号 $e m g_{1}, e m g_{2}, \cdots, e m g_{d}$ には線形関係があると仮定し，次式のような重回帰モデル が成立する。

$$
y_{i}=a_{i 0}+a_{i 1} e m g_{1}+a_{i 2} e m g_{2}+\cdots+a_{i d} e m g_{d}
$$

ここで $a$ は偏回帰係数であり最小二乗法によって推定する 4.2 教師信号生成

回帰係数ベクトルを推定するためには目的変数べクト ルの教師信号を与える必要がある. 教師信号は計測された 筋電信号から以下に記す方法で生成する.

まず, $m$ 種類の動作を一度ずつ行い，その時計測された $d$ チャンネルの筋電信号を整流・平滑化した信号を算出す る. それらの信号を次式のように総和する.

$$
S=\sum_{l=1}^{d} e m g_{l}
$$

動作を行う度に筋電波形にはピークが生じるため, $S$ には $m$ 個のピークが生じる. 生じたピークの中で $k$ 番目のピー クは $k$ 番目に行った動作（以下, 動作 $k$ と呼ぶ）に対応し ている. 動作 $k$ に対応した教師信号を以下のように求める.

$$
y t_{k}=\left\{\begin{array}{rr}
S & (i=k) \\
-S & (i \neq k)
\end{array}\right.
$$

$i$ はピークの数 $(i=1, \cdots, k, \cdots, m)$ を表す.また, 動作を行っ ていない時は 0 とした。これにより，対応する動作を行っ た時に教師信号は正の值になり，それ以外の動作を行った 時は負の值になる. $d=4, m=4$ の場合におけるこの手法 の適用例を図 4 に示す.

ここで, 説明変数ベクトルと目的変数ベクトルがリアル タイムで同時に計測されるため, 回帰係数ベクトルもリア ルタイムで推定できる.

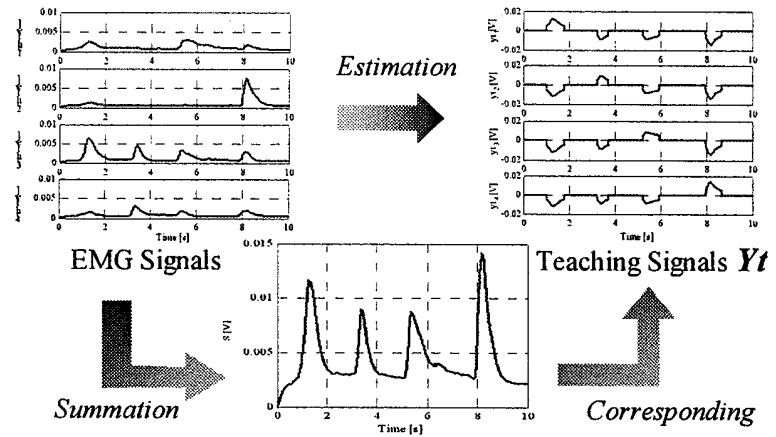

Fig.4 The Generation Method of the Teaching Signals

\section{5. 実験}

実験では提案手法を用いて肩関節と时関節における動 作識別と関節角度推定を行う。さらに，動作識別と関節角 度推定を組み合わせた切り替え制御法を用いてマニピュレ 一タを制御する，そして実験結果より，提案手法の有効性 を検証する。

\section{1 実験装置}

実験システムの全体図を図 5 に示す。マニピュレータに は 5DOF シリアルリンクマニピュレータ（ロボス製）を使 用する.このマニピュレータは人間の左上肢を模倣したも のである。その構成は，ヨー方向に 1 DOF，ロール方向に 1 DOF，ピッチ方向に 3 DOF である. マニピュレータの各 関節は， $\mathrm{AC}$ サーボモータ（松下電器産業製）によって駆 動される.また，関節角度の検出には $2500[\mathrm{pulse} / \mathrm{r}]$ の分解 能を持つエンコーダを用いる. 本研究ではこのマニピュレ 一タの肩関節と肘関節に対応する軸のみを制御する．ホス トコンピュータには, PC/AT 互換機 (PentiumIII 700[MHz], OS:Windows2000）を使用する。 また，DSP 及び A/D・D/A 変換部には, dSPACE 社製のシングルボードシステム DS1103（Power PC 400[MHz]）を用いる.

筋電計測には，ハラダ・ハイパープレシジョン製表面筋 電位測定器（電極分離型 EMG-025）を用いる。この測定 器により筋電信号は 500 倍 $(54[\mathrm{~dB}])$ に増幅される. また, 電極には MEDICOTEST 社のディスポーザブル電極 (Blue Sensor P-00-S）を使用する．筋電信号は双極誘導法によっ て計測する，増幅された筋電信号は $\mathrm{A} / \mathrm{D}$ 変換（サンプリン グ周波数 $1000[\mathrm{~Hz}]$, 分解能 $16[\mathrm{bit}]$ ）を行い, DSP に入力 する. 電極は図 6 のように有部に 2 チャンネル，上腕に 2 チャンネル, 前腕部に 2 チャンネルの合計 6 チャンネルを 配置する.また専門知識のない人が使用することを想定し， 電極の配置位置は峳密に決めなかった.アース電極は筋肉 のない时に配置することによりクロストークを防止する。

被験者は 22〜24 歳の健康な成人男性 5 人である.ただ し 5 人のうち 2 人 $(\mathrm{A}, \mathrm{B})$ は本システムの制御実験の経験 を有している. 残りの 3 人（C，D，E）は本システムの制 御経験が全く無く, 今回が初めての実験であった.
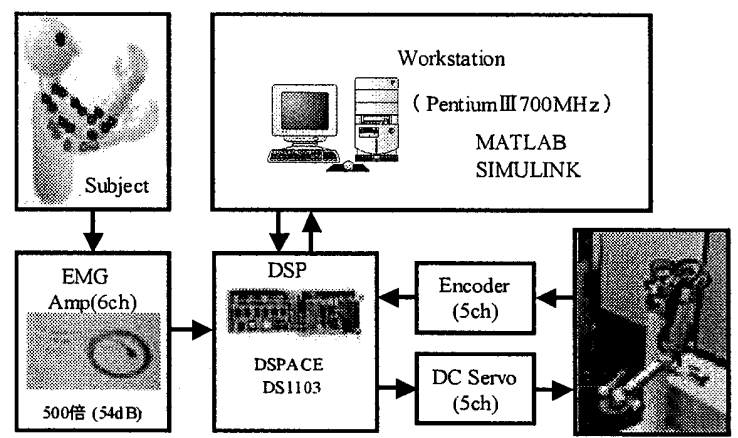

Fig.5 Experimental Setup 


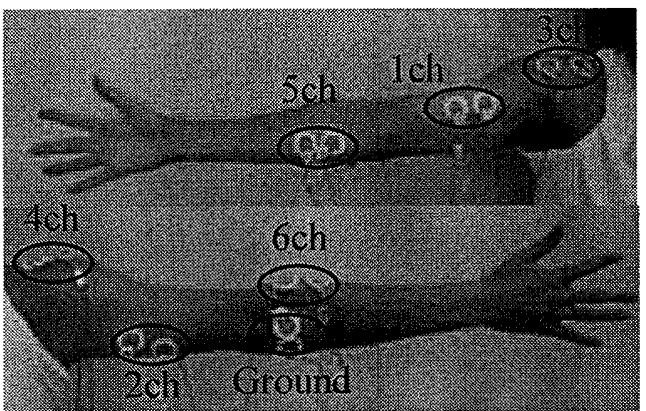

Fig.6 Location of Setting Electrodes

\section{2 制御器}

本研究では, マニピュレータの制御器として次式に示す PD 制御器を用いる

$$
\begin{array}{r}
u_{i}=K_{P i}\left(\theta_{d i}-\theta_{i}\right)+K_{D i}\left(\dot{\theta}_{d i}-\dot{\theta}_{i}\right) \\
(i=1,2,3,4,5)
\end{array}
$$

ここで， $u$ は制御入力， $\theta_{d}$ は目標角度， $\theta$ は現在の角度， $K_{p}$ は比例ゲイン, $K_{D}$ は微分ゲインであり, $i$ は各関節の軸 番号である.

\section{3 実験方法}

動作識別実験と関節角度推定実験を行い，そして動作識 別と関節角度推定を組み合わせた切り替え制御法の有効性 の検証実験を行う。

動作識別実験では，3，4ch の筋電信号を用いて肩関節の 屈曲動作と外転動作の識別を行い，1，2，5，6ch の筋電信 号を用いて肘関節の屈曲動作, 伸展動作, 回内動作, 回外 動作の識別を行う。動作識別モデルの学習は, 一度の試行 で得られた筋電信号のみを利用して行うことで，提案手法 の実用性とリアルタイムシステムへの適用可能性の検証を 行う.

関節角度推定実験では，推定した関節角度と目標角度を ディスプレイ上に表示し，推定角度が目標角度に追従する ように被験者が運動をする。目標値が一定の場合と動的に 変化する場合において実験を行う。また肩と时の両関節を 用いて任意の目標值に到達させる実験を行い，関節角度の 推定精度を検証する。

動作識別と関節角度推定を組み合わせた切り替え制御 法の有効性の検証実験では，矢状平面上にお招りる屈曲伸展 動作を行ったときのみ推定角度をマニピュレータの指令角 度とし，その他の動作を行った際は現在の関節角度を維持 するといった切り替え制御を行う。これにより肩の外転動 作及び时の回内回外動作の推定関節角度への影響を除去す る. その結果より提案手法の有効性を検証する.

5.4 動作識別実験の結果及び考察

肩関節における屈曲，外転動作を行った時の筋電信号を 図 7 に示す. この図において約 1.2 秒 4 秒において屈曲 動作, 約 4.5 秒〜 7 秒において外転動作を行った。この筋 電信号から推定された各動作の動作信号を図 8 に示す. 図 8 において上段の図は屈曲動作，下段の図は外転動作の動 作信号を示している．屈曲に対応した動作信号は屈曲動作 を行った際に正の值となり，外転動作を行った際には負の 值となっていることがわかる。一方，外転に対応した動作 信号は外転動作を行った際に正の值となり，屈曲動作を行 った際には負の值となっていることがわかる．よって，最 も大きい動作信号を出力するモデルに対応した動作を行っ たと識別することが可能である．全被験者が各動作を 20 回ずつ行い，識別精度を検証した結果，全被験者が屈曲， 外転の両動作において $100[\%]$ 識別率が得られた。

次に肘関節における屈曲, 回内, 回外, 伸展動作を行っ た時の筋電信号を図 9 に示す。この図において約 1 秒〜2

秒において屈曲動作，約 3.5 秒〜4.5 秒において回内動作， 約 5.5 秒 7 秒において回外動作, 約 8 秒 $~ 9$ 秒において伸 展動作を行った。この筋電信号から推定された各動作の動 作信号を図 10 に示す. 図 10 において, 上段から順に, 屈 曲, 回内, 回外, 伸展の動作信号を示している. 屈曲に対 応した動作信号は屈曲動作を行った際に正の值となり，そ の他の動作を行った際には負の值となっていることがわか る. 同様に回内, 回外, 伸展動作に対応する動作信号も対 応する動作を行った際のみ正の值をとり，対応しない動作 を行った際には負の值となっていることがわかる.よって 肘関節においても動作識別が可能であることがわかる.さ らに全被験者が各動作を 20 回ずつ行い, 提案手法の識別精 度を検証した。 その結果, 全被験者において 90[\%]以上の 識別率が得られた。

以上の結果から，提案手法によって肩関節の屈曲動作， 外転動作々肘の屈曲動作, 伸展動作, 回内動作, 回外動作 に対応する動作信号を生成することができ, 動作識別が可 能であることを示した。

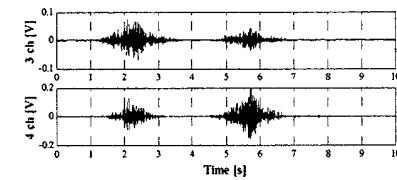

Fig.7 EMG Signals of Shoulder

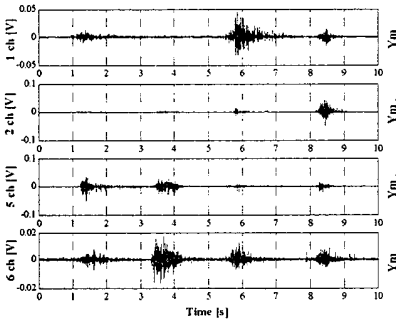

Fig.9 EMG Signals of Elbow

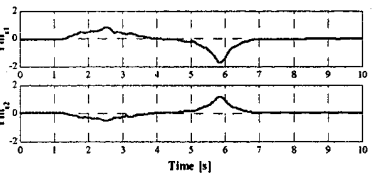

Fig.8 Motion Signals of Shoulder

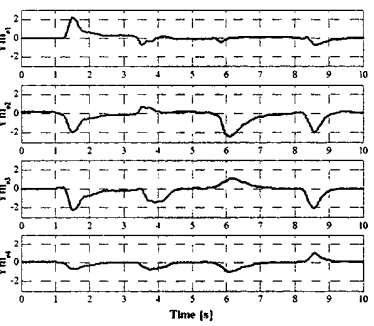

Fig.10 Motion Signals of Elbow

\section{5 関節角度推定実験の結果及び考察}

肩と时の両関節においてディスプレイ上に表示された 静的な目標値を追従しその精度を検証する。目標値は 30 , 60, 90[deg]とした。実験はそれぞれ 10 秒間行い，始めの 5 秒間で目標値に到達しその後は目標値で維持するように被 験者に指示した. 被験者 $\mathrm{A}$ における追従実験の結果を図 11, 図 12 に示す. 図 11 は肩関節, 図 12 は肘関節における結果 を示している．これらの図から精度良く目標值に追従でき ていることがわかる．また，定常状態における精度を検証 するため, 実験開始後 5 秒から 10 秒における目標值と推定 角度の差を平均追従誤差で評価した．全被験者における平 均追従誤差を図 13 , 図 14 に示す. 図 13 は肩関節, 図 14 は肘関節における結果を示している。これらの図から両関 節とも平均追従誤差は $5[\mathrm{deg}]$ 以下となっており, 追従精度 が高いことがわかる。

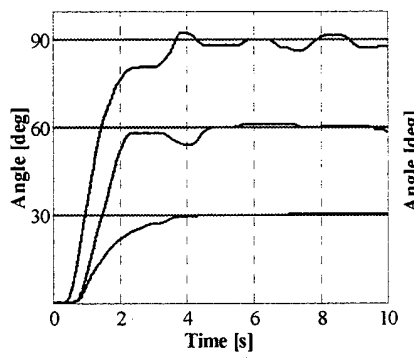

Fig.11 Shoulder Trajectory of Tracking the Static Target

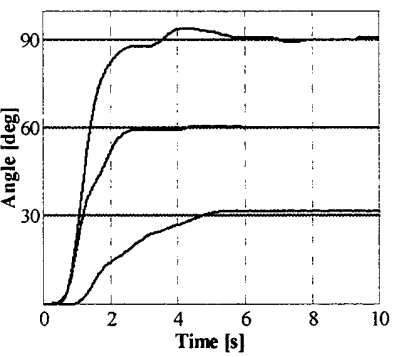

Fig.12 Elbow Trajectory of Tracking the Static Target 


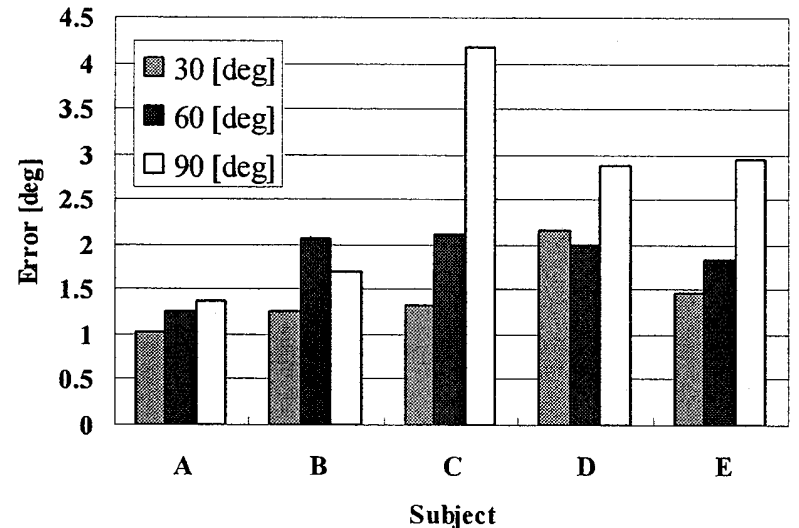

Fig.13 Tracking Error of Shoulder to the Static Target

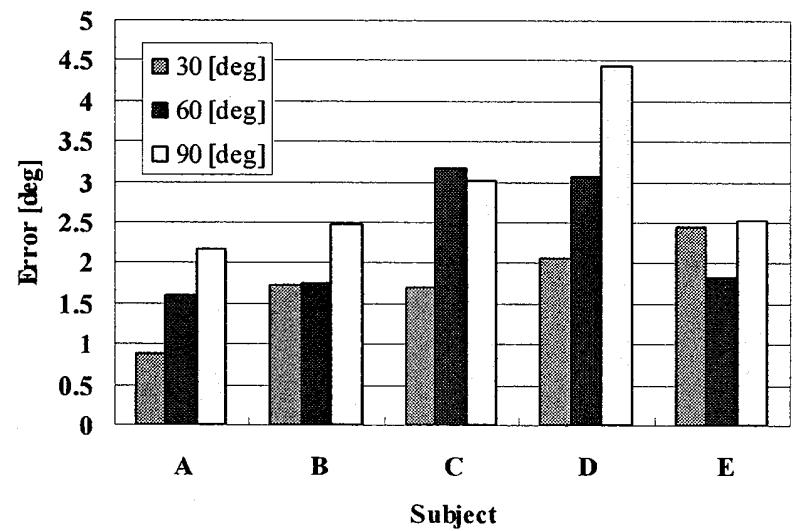

Fig.14 Tracking Error of Elbow to the Static Target

動的な目標值をディスプレイに表示し追従精度の検証 を行った. 目標值は振幅が $45[\mathrm{deg}]$ で周波数が $0.1 \sim 0.2[\mathrm{~Hz}]$ に変化するチャープ信号である。被験者 A における追従実 験の結果を図 15 , 図 16 に示寸. 図 15 は肩関節, 図 16 は 肘関節における結果を示している。 これらの図から推定軌 道は目標軌道に対して波形の傾向が良く一致してことがわ かる. 全被験者における平均追従誤差を図 17 に示す。この 図から平均追従誤差は 25[deg]以下であり, 上記の目標值を 固定した場合よりも，追従誤差が大きくなっていることが わかる. その誤差の原因はディスプレイの表示に時間遅れ があるため追従を行うのが困難であったものと考えられる 次に両関節の運動によって静止している物体への追従実験 を行った. 目標物体は 3 つ設置し, 表 1 に示した位置で静 止しているものとする．肩関節と肘関節の両方の関節角度 を推定し（Target1〜3），マニピュレータの手先を目標物 体の位置に到達するように制御した. 図 18 に実験の様子と, マニピュレータの先端部の軌道を示す。この図からマニピ ュレータの手先位置は滑らかに目標值に到達できているこ とがわかる.また追従誤差の平均値は $30[\mathrm{~mm}]$ 以下であった. これらの結果から，提案手法による関節角度推定を用いる ことでマニピュレータを高精度で制御できることを示した。

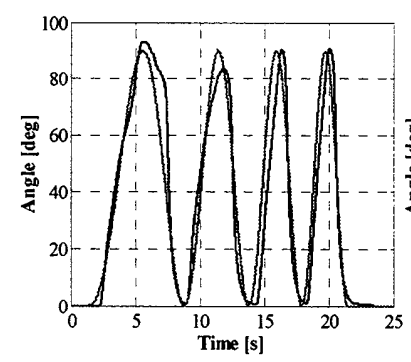

Fig.15 Shoulder Trajectory of Tracking the Dynamic Target

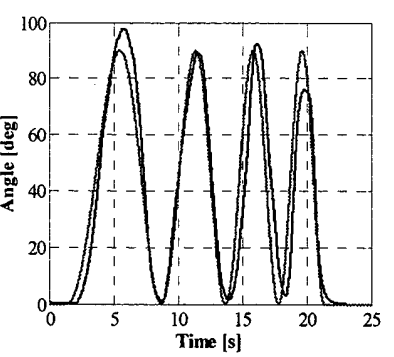

Fig.16 Elbow Trajectory of Tracking the Dynamic Target

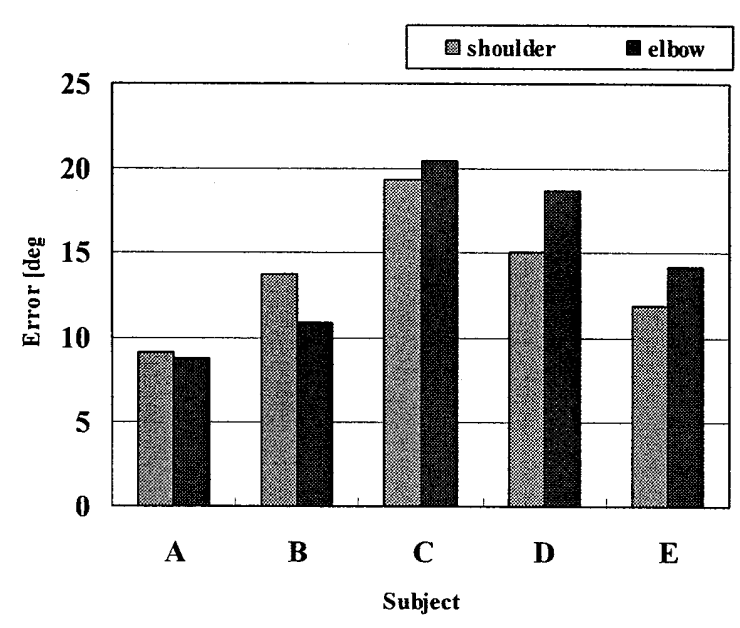

Fig.17 Tracking Error to Dynamic Target

Table 1 Positions of Targets

\begin{tabular}{c|c}
\hline \hline & Position $(\mathrm{y}[\mathrm{m}], \mathrm{z}[\mathrm{m}])$ \\
\hline Target1 & $(0.164,0.463)$ \\
\hline Target2 & $(-0.002,0.460)$ \\
\hline Target3 & $(-0.216,0.458)$ \\
\hline
\end{tabular}
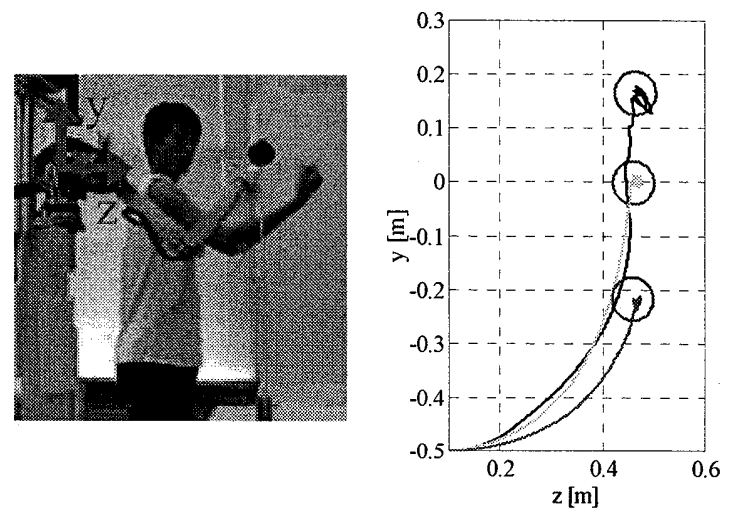

Fig.18 Picture and Trajectory of Tracking the Static Target

\section{6 切り替え制御実験の結果及び考察}

この実験では, 肩の屈曲, 外転動作, 肘の屈曲, 回内, 回外, 伸展動作を行う. 図 19 には肩関節において屈曲動作 と外転動作を行った時の推定関節角度を示す。この図にお いて赤の破線は動作識別を行わなかった場合の推定角度で あり，屈曲動作（約 0.5 秒 $\sim 5$ 秒） と外転動作（約 5 秒 $~ 8$ 秒）の両方の動作において推定角度が変化していることが わかる. 一方，青線は動作識別を行った場合の推定角度で あり，屈曲動作を行った際にはマニピュレータの関節角度 が変化し屈曲動作を行っているが，外転動作には反応して いないことがわかる。この結果から，提案手法による肩関 節における動作識別が有効であることが示された．また同 様に図 20 に时関節において屈曲動作（約 1 秒 $４$ 秒），回 内動作（約 4 秒 $\sim 6$ 秒），回外動作（約 6 秒 7.5 秒），伸 展動作（約 7.5 秒〜10 秒）を行った時の肘関節角度の推定 値を示す。この図において動作識別を行うことによって回 内回外動作の影響を低減できていることがわかる．屈曲動 作から回内動作の間や回外動作から伸展動作の間において, 識別結果が不安定になり推定角度に影響を与えているが 2[deg]程度であった．上で述べた静的な目標角度追従実験 における平均誤差が $5[\mathrm{deg}]$ 以下の精度であったため，回内 回外動作による影響は除去できたと言える.この結果から， 提案手法による動作識別が有効であることが示された。 


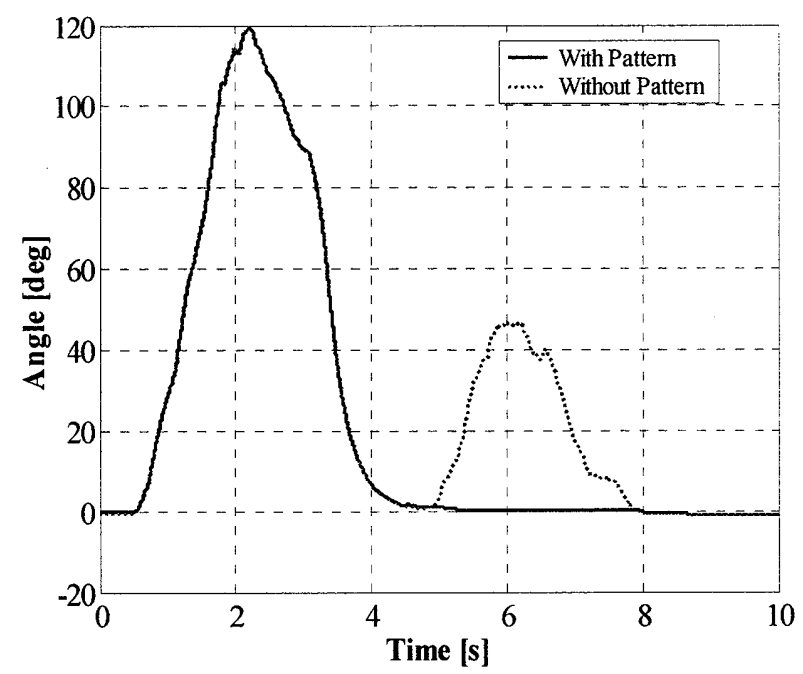

Fig.19 Predicted Angle of Shoulder

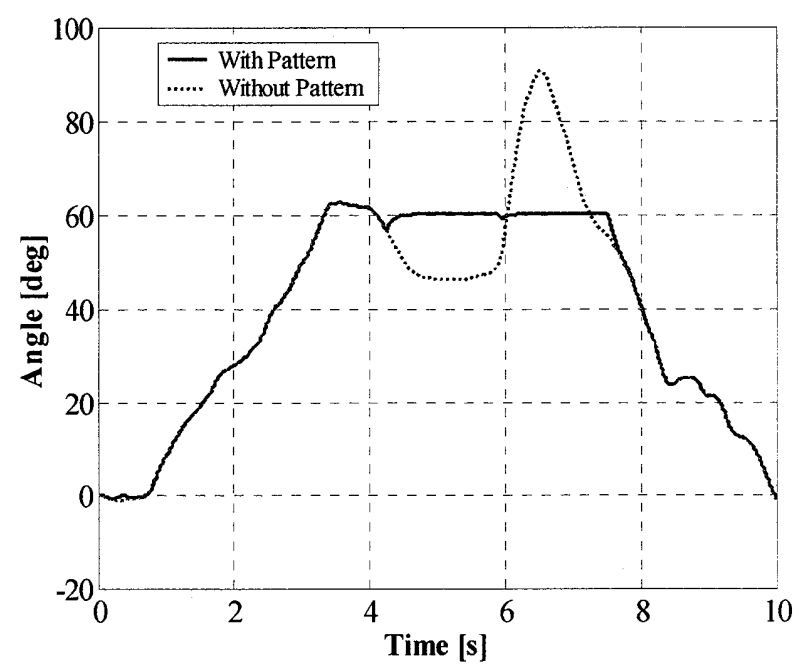

Fig.20 Predicted Angle of Elbow

\section{6. 結言}

本研究では, 筋電信号を用いたロボットマニピュレーシ ヨンシステムの構築を目的とし，筋電信号から動作識別と 関節角度の推定を行う手法を提案した．複数の被験者にお いて提案手法の検証実験を行った結果, 以下の結論を得た.

1. 提案手法によって肩関節の屈曲動作と外転動作, 肘関 節の屈曲伸展動作, 回内回外動作の動作識別が可能で ある。

2. 提案手法によって局関節と时関節の屈曲伸展動作時に おける関節角度を高精度に推定することが可能である

3. 動作識別と関節角度の推定を組み合わせた切り替え制 御法によって，マニピュレータに所望の動作のみを行 わせることが可能である.

4. 構築した筋電制御型マニピュレーションシステムは複 数の被験者における個人差に短時間で適応することが 可能である.

\section{謝辞}

なお本研究は，文部科学省の事業の一つである，関西文 化学術研究都市 地域 知的クラスター創成事業「高度マン マシンインターフェイス技術群のネオカデンへの応用に関 する研究」における研究の一環として行った。
参考文献

1) O. A. Alsayegh, D. P. Brzakovic, Guidance of Video Data Acquisition by Myoelectric Signals for Smart Human-Robot Interfaces, Proceedings of the 1998 IEEE International Conference on Robotics\& Automation, 3179-3185(1998).

2）小池康晴, 川人光男, 神経回路モデルを用いた表面筋 電信号からの人腕の軌道生成, 電子情報通信学会論文 誌 D-II, J77-D-II, No.1, 198-203(1994).

3) Kurt Manala, Roger V. Gonzalezb, David G. Lloydc, Thomas S. Buchanana, A real-time EMG-driven vir-tual arm, Computers in Biology and Medicine 32, 2536(2002).

4) Edward A. Clancy, Stephane Bouchad, Denis Ran-court, Estimation and Application of EMG Amplitude During Dynamic Contractions, IEEE Engineering In Medicine And Biology, 20(6), 47-54(2001).

5) Jason J. Kutch, Thomas S. Buchanan, Human elbow joint torque is linearly encoded in electromyographic signals from multiple muscles, Neuroscience Letters 311, 97100(2001).

6) Christian Fleischer, Konstantin Kondak, Christian Reinicke, Gunter Hommel, Online Calibration of the EMG to Force Relationship, Proceedings of 2004 IEEE/RSJ International Conference on Intelligent Ro-bots and Systems , 1305-1310(2004).

7) Srikanth Suryanarayanan, Narender P. Reddy, EMG-Based Interface for Position Tracking and Control in VR Environments and Teleoperation, Presence, Vol. 6, 282-291(1997).

8) Arthur T. C. Au, Robert F. Kirsch, EMG-Based Prediction of Shoulder and Elbow Kinematics in Able-Bodied and Spinal Cord Injured Individuals, IEEE Trans Rehabilitation Engineering, 8(4), 471-480(2000).

9) 西川大亮, 俞文偉, 横井浩史, 嘉数侑昇, 筋電義手制 御のためのオンライン学習法, 電子通信情報論文誌 D-II, J82-D-II, No.9, 1510-1519(1999).

10）辻敏夫, 重吉宏樹, 福田修, 金子真, EMG 信号に基づ く前腕動力義手のバイオミメティック制御, 日本機械 学会誌論文集 (C 編)，66 巻, 648 号, 2764-2771(2000).

11) KristinA.Farry, IanD.Walker, Richard, Myoelectric Teleoperation of a Complex Robotic Hand, IEEE Trans Robotics and Automation, 12(5), 775-788(1996).

12) 内田雅文, 井出英人, 横山修一, 筋電位を用いた手指 動作ロボット, 電気学会論文集, Vol.118-A, No.3, 204-209(1998).

13）藤原義久，前川聡，独立成分分析による筋電データか らの各指運動の分離, 信学技報, MBE99-7，41-46(1999). 